\title{
PERANCANGAN DESAIN KOMUNIKASI VISUAL FILOSOFI SURJAN JOGJA MENGGUNAKAN METODE DESIGN THINKING
}

\author{
Wuri Septiningsih \\ Universitas Jendral Sudirman Purwokerto \\ wuriseptianingsih@yahoo.com
}

\begin{abstract}
Abstrak
Metode Design Thinking dikembangkan serta dipopulerkan oleh David Kelley dan Tim Brown. Metode ini digunakan sebagai acuan dalam Practical Based Design Research yang berpusat pada kebutuhan manusia - human centered. Metode ini akan digunakan dalam perancangan desain komunikasi visual guna mengenalkan Filosofi Surjan Jogja. Surjan sebagai pakaian adat Jawa (Jogja) dapat dipelajari sebagai bentuk hasil kebudayaan, nilai, norma, kepercayaan, sistem sosial dan budaya, sistem ekonomi, mata pencaharian dan adat istiadat. Hal tersebut dapat diartikan sebagai alat komunikasi nonverbal yang menjadi simbol ikonik yang menunjukkan batas-batas budaya dengan nilai budaya lainnya di Indonesia. Berdasarkan data survey penyebaran 50 lembar angket pada sampel yang diambil, tak banyak yang mengetahui bahwa bentuk baju surjan memiliki berbagai makna filosofis. Hal tersebut dapat diperkenalkan salah satunya yaitu dengan cara membuat perancangan desain untuk memberikan informasi mengenai falsafah budaya yang terkandung dalam Surjan Jogja. Untuk dapat merancang desain tersebut dibutuhkan beberapa data. Pencarian data akan menggunakan metode survey, wawancara, dan mencari sumber pustaka pendukung. Teori sosial milik Barthes akan digunakan dalam analisis sosial dan sebagai teori penunjang semiotika dalam pendekatan post-modernisme dan seni budaya.
\end{abstract}

Kata Kunci : Design Thinking, Surjan, Filosofi, Informasi

\begin{abstract}
Design Thinking method was developed and popularized by David Kelley and Tim Brown. This method is used as a reference in Practical Based Design Research, centered on human needs. This method will be used for making visual communication design to introduce the philosophy of Surjan Jogja. Surjan as Javanese outfit (Yogyakarta) can be studied as a form of culture, values, norms, beliefs, social and cultural systems, economic systems, livelihood and customs. This can be interpreted as a means of nonverbal communication that became an iconic symbol that shows the boundaries of culture with other cultural values in Indonesia. Based on data from the deployment of 50 sheet questionnaire survey on samples taken, not many know that the form of clothes Surjan has a variety of philosophical meaning. It can be introduced by making designing to provide information about cultural philosophy contained in Surjan Jogja. Data research taking by surveys, interviews, and looking for support literature sources. Barthes's social theory analysis and semiotics theory of post-modernism and cultural arts will be used as supporting analysis.
\end{abstract}

Keywords: Design Thinking, Surjan, Philosophy, Information 


\section{Pendahuluan}

Tahapan metode Design Thinking Brown sangat jarang sekali dibahas secara detail oleh desainer dalam membuat suatu perancangan desain komunikasi visual. Padahal dalam merancang suatu desain informasi tahapan ini dapat dijadikan acuan arah pengembangan inovasi yang berpusat pada kebutuhan manusia. Karena manusia itu sendiri adalah target sasaran desain informasi. Brown memetakan 3 ruang (space) agar inovasi dapat berjalan atau terjadi, yaitu: inspiration, permasalahan atau kesempatan yang mendorong terjadinya pemecahan permasalahan; ideation (proses membiak-kan, mengembangkan dan menguji ide) dan implementation, perancangan skema produksi hingga digunakan oleh masyarakat luas.

Design Thinking dilandasi kebutuhan untuk berinovasi secara cepat, tepat dan akurat berorientasi pada manusia-nya (human-centered). Maka yang pertama kali harus dilakukan adalah dengan mengumpulkan insight (sebagai upaya belajar dari orang lain), melakukan observation (memerhatikan apa yang orang tidak lakukan, mendengarkan apa yang orang tidak katakan), ber-empathy (merasakan dan mencoba berganti posisi menjadi orang lain), menangkap pola (pattern) dan kemudian mencoba memikirkan melampaui itu, beyond individual. Sehingga kemudian kita dapat menarik dan membuat point of view.

Dalam pola Design Thinking proses ini harus kolaboratif, melibatkan berbagai disiplin ilmu yang diharapkan ada inovasi baru yang muncul. Bagian ini disebut sebagai Inspiration. Selanjutnya adalah proses Ideation. Tahap ini dimulai dengan cara berpikir divergen- biasanya di awal untuk menciptakan berbagai macam pilihan dan konvergen biasanya di akhir untuk membuat serta memilih pilihan yang paling tepat. Ini disebut sebagai convergent and divergent thinking serta melakukan proses analisis dan sintesis. Proses ini didukung dengan sikap yang terbuka untuk bereksperimen, mengembangkan optimisme dan selalu terbuka untuk brainstorming process, belajar untuk selalu berpikir visual. Salah satu hal yang sangat penting di tahap ini adalah membangun ide kita melalui prototyping, yaitu membuat dan menjadikan secara nyata apa yang telah kita analisis dan sintesis-kan pada tahap sebelumnya. Prototipe memiliki tujuan untuk menemukan kelemahan dan kelebihan dari sebuah ide dan menemukan arah menuju prototype yang lebih baik lagi.

Tahap berikutnya adalah proses implementation, mengekskusi apa yang menjadi visi dan tujuan desain menjadi prototipe. Berpikir secara komprehensif bagaimana mengantarkan sebuah prototipe untuk dapat dilaksanakan secara nyata, bagaimana produksi-nya, bagaimana moda distribusi dan implementasi-nya, bagaimana evaluasi-nya dan hingga akhir bagaimana kemudian kelangsungan selanjutnya. Tujuan dalam perancangan karya ini adalah untuk memudahkan masyarakat awam dalam mengenal makna falsafah Surjan. Serta membantu dalam melestarikan kembali baju identitas jawa khususnya Jogja. 


\section{Metode Penciptaan}

Metode Design Thinking

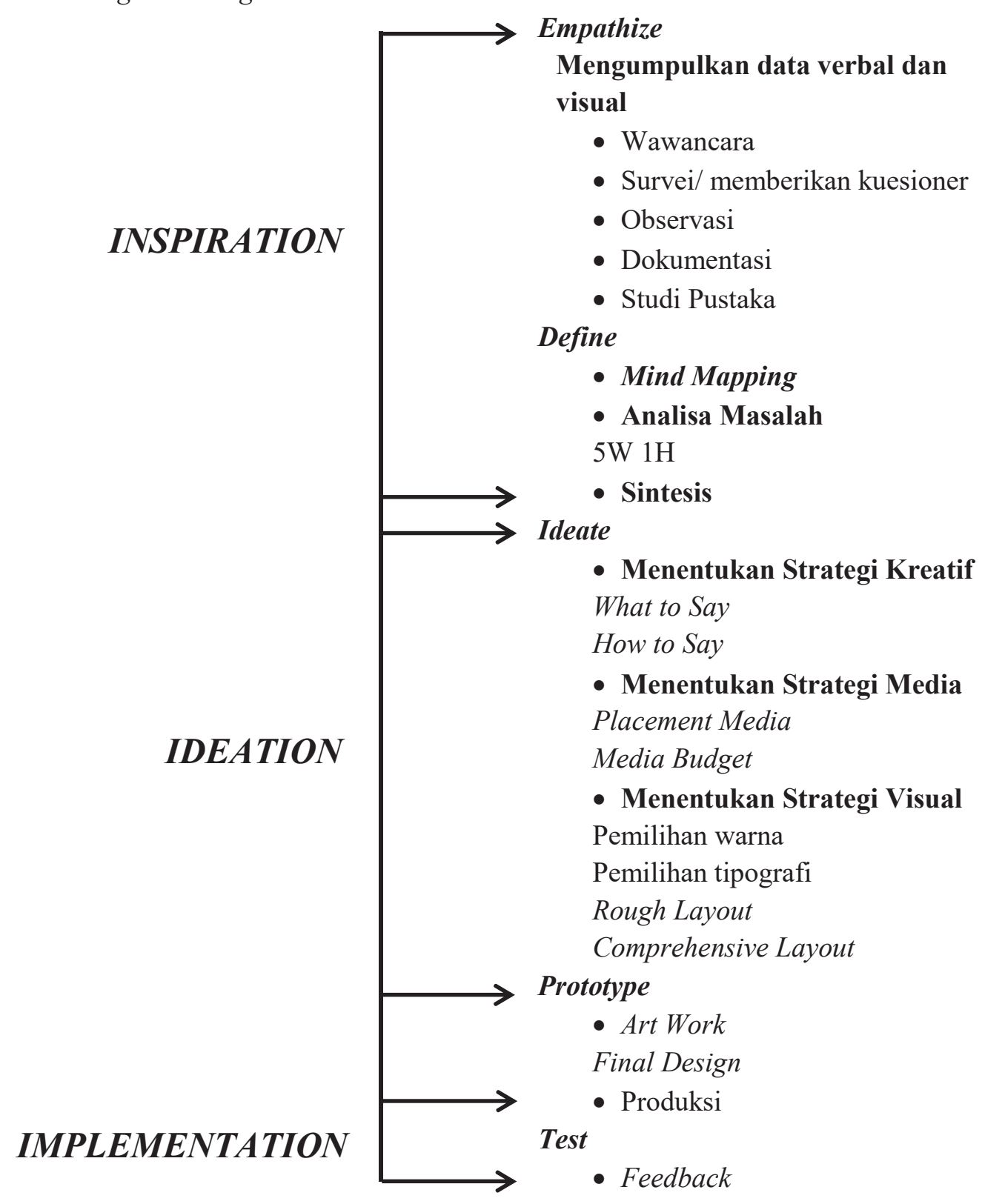

\section{Pengumpulan Data}

Data yang dibutuhkan dalam perancangan ini dalam membangun sebuah rancangan desain yang sesuai dengan Design Thinking adalah data visual dan data verbal. Data tersebut akan didapatkan dengan rangkaian proses sebagai berikut. 


\section{a. Metode Pengumpulan Data}

Pengumpulan data dalam perancangan ini mencakup pencarian data dari kepustakaan, media internet, angket, observasi data lapangan, serta wawancara narasumber pihak yang terkait. Data yang didapatkan kemudian ditarik kesimpulan untuk dijadikan desain komunikasi visual yang efektif dan informatif.

\section{Data Primer}

\section{a. Wawancara}

Wawancara mencakup ranah pendalaman filosofi, mitos, makna, sejarah dan informasi-informasi penting lainnya terkait baju Surjan kepada ahli budaya, sejarawan, dan abdi dalem Karaton Ngayogyakarta Hadiningrat.

\section{b. Memberikan Kuesioner}

Menyebar kuesioner secara random (acak) pada masyarakat umum, untuk mengetahui seberapa jauh tingkat pengetahuan masyarakat terhadap baju surjan. Teknik pengambilan sampel data kuantitatif dilakukan berdasarkan sampel ketersediaan (availability samples). Sampel ketersediaan adalah sampel yang unsur-unsurnya diambil atas dasar kemudahannya dijangkau oleh peneliti. (Walizer dan Wienir terjemahan oleh Arif Sukardi Sadiman, 1987: 141). Sampel yang tersedia dalam penelitian ini sangat random (acak) mulai dari anak muda usia remaja-dewasa, tukang becak di malioboro, kusir, masyarakat awam yang sedang berlibur di jogja, abdi dalem, mahasiswa. Pertanyaan 1-5 mengidentifikasi pengetahuan terhadap pengageman takwa. Pertanyaan ke- 6 akan menjawab pentingnya tema ini diangkat dan dibuat desainnya guna mengkomunikasikan suatu informasi kepada masyarakat.

\section{c. Observasi}

Melakukan pengamatan obyek secara langsung terhadap masyarakat umum yang menggunakan pakaian takwa/surjan di sekitaran kota Jogja.

\section{d. Dokumentasi}

Setelah melakukan pengamatan dengan cara observasi data secara langsung dan melakukan wawancara, maka selanjutnya melakukan penelitian dengan cara dokumentasi yaitu mengambil foto atau gambar tentang objek yang diteliti.

\section{Data Sekunder}

Data sekunder merupakan data pendukung yang diperoleh peneliti melalui sumber kedua atau sumber sekunder (Bungin, 2008: 128). Data sekunder merupakan data pendukung yang diperoleh dari literatur kepustakaan, jurnal ilmiah, artikel di media cetak, website dan tulisan lain yang relevan dengan penelitian ini.

\section{a. Studi Pustaka}

Melakukan penelitian dengan cara mempelajari dan membaca literatur-literatur yang berhubungan dengan permasalahan yang menjadi obyek penelitian yaitu menyampaikan pesan yang informatif, komunikatif, dan efektif mengenai keistimewaan baju takwa/surjan, dimana terkandung nilai-nilai adiluhung, sejarah, fungsi, filosofi, dan sebagai simbol budaya didalamnya. 


\section{Temuan dan Pembahasan}

Surjan menurut K.R.T. Jatiningrat (2016) merupakan baju adat dari keraton mataram yang diciptakan oleh Sunan Kalijaga berdasar ayat suci umat Islam yaitu Al-Qur'an. Oleh Sunan Kalijaga dijadikan model pakaian rohani (takwa) agar si pemakai selalu ingat kepada Allah SWT, kemudian oleh raja-raja Mataram pakaian takwa ini dipakai hingga saat ini. Bentuk pakaian Takwa adalah; Lengan panjang, ujung baju runcing, leher dengan kancing tiga pasang (berjumlah 6), dua kancing di dada kanan kiri, tiga buah kancing tertutup. Bentuk tersebut sesungguhnya memiliki makna tertentu di setiap bagiannya yang jarang diketahui oleh masyarakat pada umumnya.

Pakaian Takwa ini di dalam Kraton hanya dipakai oleh Sri Sultan dan Pangeran Putra Dalem. Sedang pakaian takwa untuk putri (Pengageman Janggan) dikenakan untuk Para Abdi Dalem Putri dan Keparak Para Gusti dengan warna kain hitam. Pada awalnya baju surjan hanya memiliki satu motif yaitu lurik dan kemudian disebut surjan lurik. Surjan inilah yang pertama kali di buat oleh Sunan Kalijaga sebagai pakaian Takwa (K.R.T. Jatiningrat, 2016). Berikut adalah bentuk baju takwa atau disebut dengan surjan.
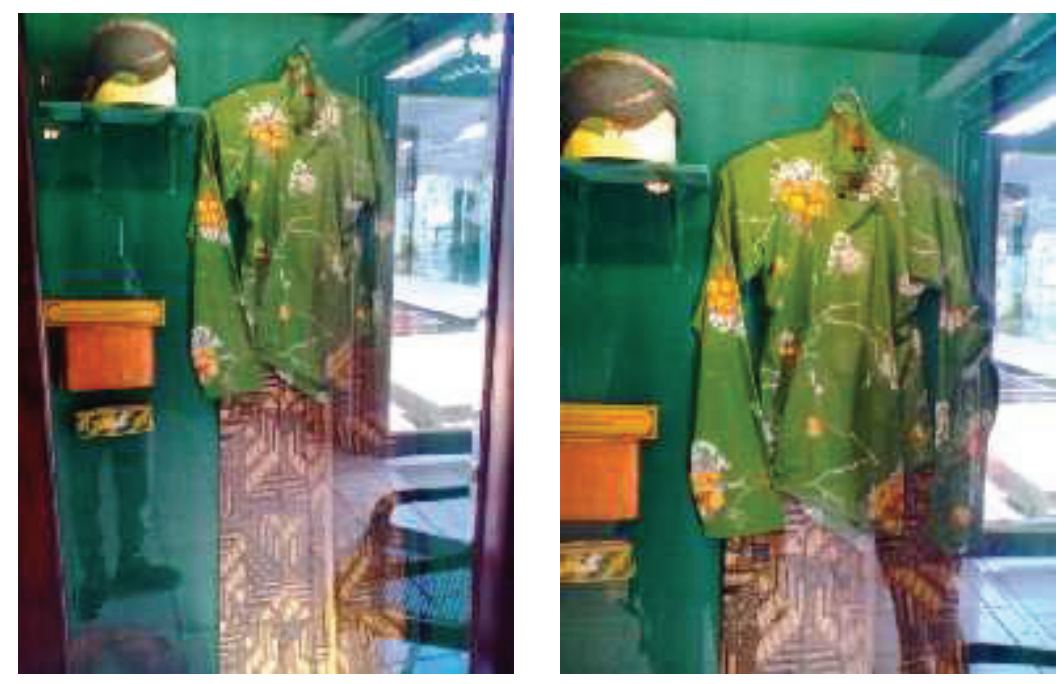

Foto 1 dan 2: Surjan Sri Sultan Hamengku Buwana, Museum Karaton Ngayogyakarto Hadiningrat, 2016. Sumber: Dokumentasi Pribadi, 2016

Dari segi pemakaian Surjan, pada zaman dulu ketika orang ingin mengenakan baju Surjan, orang tersebut harus menggunakan busana lengkap seperti memakai iket, jarik, dan slop (sandal adat jawa). Orang yang tidak mengenakan busana secara lengkap dikatakan orang yang tidak tau adat. Namun dalam perkembanganya, pada zaman sekrang banyak orang yang menggunakan surjan dengan bawahan celana levis tanpa memakai perlengkapan adat lainnya. Hal ini bisa disebut sebagai suatu cara agar baju 
surjan tetap eksis di zaman sekarang terlepas dari aturan yang berlaku pada zaman dahulu.

Terlepas dari pakem menggunakan baju surjan yang benar, sebenarnya dalam sebuah pakaian menyampaikan komunikasi simbolik sebuah kebudayaan. Bahwa dalam sebuah baju surjan memiliki nilai-nilai luhur yaitu sebagai simbol ketakwaan, persatuan dan kesatuan. Semua orang saat ini boleh menggunakan baju surjan dengan cara apapun. Dengan menggunakan baju surjan maka kita dapat menjadi simbol Abdi Budaya di dalam sebuah masyarakat.

Berdasarkan data survey penyebaran 50 lembar angket pada sampel yang diambil. Sampel yang diambil dalam penelitian ini sangat random (acak) mulai dari anak muda usia remaja-dewasa, tukang becak di Malioboro, kusir, masyarakat awam yang sedang berlibur di Jogja, abdi dalem, mahasiswa. Angket berisi 6 pertanyaan, pertanyaan 1-5 yang mengidentifikasi pengetahuan terhadap pengageman takwa. Sedangkan Pertanyaan ke-6 akan menjawab pentingnya tema ini diangkat dan dibuat desainnya guna mengkomunikasikan suatu informasi kepada masyarakat.

Hasilnya adalah 53\% mengetahui apa itu baju surjan sedangkan $47 \%$ sampel menjawab tidak tahu. Masyarakat (sampel) yang mengetahui asal baju surjan 52\% menjawab baju jawa/ Jogja, 48\% menjawab tidak tahu asalnya. Pengetahuan masyarakat terhadap makna baju surjan sangat rendah, yaitu $8 \%$ menjawab tahu selebihnya $92 \%$ menjawab tidak tahu. Kebanyakan sampel masyarakat tidak mengetahui jenis-jenis surjan 97\%, dan hanya 3\% yang mengetahui jenisnya. Sampel masyarakat di sekitar wilayah Jogja pernah memakai baju surjan 37\% menjawab pernah memakai dan 63\% menjawab tidak pernah.

Berdasarkan data tersebut tak banyak yang mengetahui bahwa surjan, baju khas Jawa, merupakan representasi dari baju Muslim. Banyak yang menganggap surjan sekadar tradisi adat istiadat. Padahal, baju tersebut menyimpan ajaran Sunan Kalijaga dan memiliki berbagai makna filosofis.

Hasil persentase pertanyaan ke - 6 yang menjawab pentingnya dibuat sebuah desain guna mengkomunikasikan suatu informasi kepada masyarakat tentang surjan/ ageman takwa sangat tinggi persentasenya pada jawaban "Ya" (tertarik) yaitu 97\% selebihnya $3 \%$ menjawab tidak tertarik.

\section{Kajian Sumber Penciptaan}

\section{A. Kajian Jurnal IImiah}

Judul 1: Penerapan Design Thinking dalam Inovasi Pembelajaran Desain dan Arsitektur oleh Filipus Priyo Suprobo. Widya Kartika University.

Dalam jurnalnya disebutkan bahwa Design Thinking sebagai pola pikir, metode, dan perangkat kerja telah memberi warna dalam pembelajaran desain dan arsitektur dengan menerapkan 5 (lima) tahapannya yang terdiri atas discovery, interpretation, ideation, experiment, dan evolution. Hasil penelitian ini menyebutkan design thinking sebagai pola pikir, metode, dan perangkat kerja telah memberi warna dalam pembelajaran desain dan arsitektur dengan menerapkan 5 (lima) tahapannya yang terdiri atas discovery, interpretation, ideation, experiment, dan evolution. Hal ini juga telah memberikan 
tingkat keberhasilannya yang tinggi melalui pengukuran selfefficacy atau dorongan diri para mahasiswa dalam menyelesaikan tugas.

Judul 2: Pemahaman Critical Thingking, Design Thinking dan Problem solving dalam Proses Desain oleh Yunida Sofiana. Interior Design Department, School of Design, BINUS University.

Berdasarkan pengamatan yang dilakukan pada insitusi pendidikan menurutnya, proses mendesain yang diakukan di dalam dunia pedidikan lebih banyak menyentuh pada permasalahan yang sifatnya umum dan sekedar memperindah suatu bentuk. Tujuan dari penulisan ini adalah untuk mengingatkan kembali perlunya proses desain diiringi dengan pola berpikir kritis dan kreatif dalam mencari solusi permasalahan desain. Sehingga desain yang dihasilkan, akan memiliki kualitas dan variasi lebih baik setelah melalui pemikiran yang lebih mendalam. Metode penelitian yang dilakukan merupakan penelitian deskriptif-kualitatif yang diambil dari berbagai sumber buku, internet dan tugas mahasiswa. Data-data dirangkum dan di analisa lalu dibuatkan sebuah kesimpulan. Dalam penelitian ini hasil yang ditemukan yaitu dalam pendidikan desain, umumnya proyek yang diberikan harus dapat melalui kriteria standar yang diberikan oleh pengajar. Kriteria ini digunakan untuk menghindari pendekatan subjektif dalam memberikan penilaian dan evaluasi. Desain memiliki tahapan-tahapan yang harus dilakukan, mulai dari proses programming, schematic, design development hingga contract administration ataupun tender. Tahapan tersebut membantu desainer dalam mengontrol setiap proses yang dilakukan, walaupun proses tersebut tidaklah harus berurutan satu dengan yang lain karena setiap desain memiliki kompleksitas dan kesulitan yang berbeda-beda tingkatannya, sehingga proses yang dilakukan tidak akan sama. Adapun hasil yang dicapai adalah desain yang maksimal dan memenuhi harapan klien/konsumen.

\section{Judul 3: Kajian Design Thinking: Proses Metakognisi dalam Pelaksanaan Proyek Desain Produk (Studi Kasus Proyek Studio Desain Produk bertema Eksplorasi Bentuk) oleh F. Priyo Suprobo, S.T., M.T. Fakultas Teknik, Universitas Widya Kartika Surabaya.}

Tujuan utama penelitian ini secara khusus mengungkap informasi yang berkaitan dengan (1) Kemampuan para pelaksana desain dalam mendefinisikan masalah dan dirinya sebagai problem solver, menentukan strategi penyelesaian, dan menceritakan situasi yang dialami saat strategi penyelesaian masalah dilakukan (gambaran metacognitive knowledge) yang terjadi selama proses penerapan design thinking dalam proyek desain produk. (2) Kemampuan para pelaksana desain dalam merencanakan, memonitor, dan mengevaluasi (gambaran metacognitive skill) masalah yang dihadapi yang terjadi selama proses penerapan design thinking dalam proyek desain produk.

Hasil penelitian menunjukkan bahwa metode design thinking dapat menjadi pedoman kognisi pengetahuan dan manifestasi keterampilan kognisi dalam sebuah proyek desain. Kategori pedoman kognisi yang diperlukan di saat menjalankan proyek desain berbasis Design Thinking meliputi: 
- Declarative knowledge: pengetahuan awal atas suatu proyek desain sangat diperlukan dan dapat diperdalam melalui pencarian sumber informasi dari luar maupun mengetahui informasi awal yang seadanya dulu, lalu langsung melakukan pengamatan ataupun pengujian pada obyek tugas.

- Procedural knowledge: dikembangkan pemikiran dan keyakinan bagi pelaksana bahwa untuk berhasil menyelesaikan tugas harus melakukan studi lapangan, praktek: belajar sambil melakukan, dan kerja sama antarpeserta sebagai tim.

- Conditional knowledge: dikembangkan pemikiran dan keyakinan bagi pelaksana untuk menyelesaikan tugas dengan semangat fleksibilitas dan motivasi yang tinggi. Fleksibilitas haruslah dimunculkan dari situasi untuk terbuka menerima masukan dan terbuka untuk bekerja sama.

Sedangkan dimensi pedoman manifestasi ketrampilan kognisi yang diperlukan di saat menjalankan proyek desain berbasis design thinking yaitu melakukan (planning) perekaman dokumen perencanaan proyek dari pemberi tugas, baik dalam bentuk pencatatan, print (hardcopy) ataupun softcopy.

Penelitian dengan metode ini dianggap berhasil oleh peneliti. Proyek Studio Desain Produk bertema Eksplorasi Bentuk dengan metode design thinking dapat menjadi pedoman dalam mencari informasi dan tanggapan para konsumen tentang produk yang dibuat serta dapat menjadi pedoman evaluasi untuk memperbaiki kesalahan dalam menciptakan produk.

Ketiga judul jurnal ilmiah tersebut menggunakan metode design thinking sebagai acuan dalam project design-nya. Dua diantaranya sebagai acuan dalam desain arsitektur, dan satu lagi desain studio dalam membuat eksplorasi bentuk. Ketiganya yang dari ketiga penelitian jurnal ilmiah tersebut yang membedakan dengan jurnal ini adalah bahwa metode ini digunakan untuk membuat perancangan desain komunikasi visual guna memberikan informasi mengenai falsafah budaya yang terkandung dalam Surjan Jogja. Untuk dapat merancang desain tersebut dibutuhkan beberapa data. Data tersebut tentunya mengacu pada proses berpikir metode design thinking. Selanjutnya data tersebut digunakan sebagai acuan dalam perancangan desain komunikasi visual kepada target audiens dengan tujuan memberikan informasi yang memiliki edukasi sejarah. Acuan tersebut akan digunakan dalam membuat perancangan yang dianggap paling tepat untuk target audiens sesuai dengan umur konsumernya.

\section{B. Kajian Data Verbal}

\section{Sejarah Pengageman Takwa (Surjan)}

Pengageman Jawa sebagai penutup badan dibuat oleh Sunan Kalijaga berdasar QS Al-A'raf 26: 'Hai anak Adam, sesungguhnya Kami telah menurunkan kepadamu pakaian untuk menutup auratmu dan pakaian indah untuk perhiasan. Dan pakaian takwa (dimaksud agar selalu bertakwa kepada Allah SWT) itulah yang paling baik. Yang demikian itu adalah sebahagian dari tanda-tanda kekuasaan Allah, mudah-mudahan mereka selalu ingat." Oleh Sunan Kalijaga pengertian ayat di atas dijadikan model pakaian rohani (takwa) agar si pemakai selalu ingat kepada Allah SWT, kemudian oleh raja-raja Mataram pakaian takwa ini dipakai hingga sekarang ini. 
Setelah perjanjian Giyanti tahun 1755, Sultan HB I menanyakan perihal pakaian yang perlu diatur kepada Susuhunan Paku Buwana III. Pangeran Mangkubumi mengatakan bahwa Ngayogyakarta sudah siap dengan rencana mewujudkan model 'pakaian takwa', sedang PB III mengatakan belum siap. Lalu Mangkubumi memperlihatkan rencana pakaian tersebut dan mengatakan jika dikehendaki dipersilahkan dipergunakan oleh Surakarta Hadiningrat. PB III setuju sambil menanyakan bagaimana dengan pakaian Ngayogyakarta, yang dijawab bahwa untuk Ngayogyakarta akan melanjutkan saja pengageman takwa dari Mataram yang sudah ada.

Pakaian takwa sering disebut SURJAN (sirajan) yang berarti Pepadhang atau Pelita. Di dalam ajarannya HB I bercita-cita agar pimpinan Negara dan Penggawa Kerajaan memiliki Jiwa dan Watak SATRIYA, dimana tidak akan lepas dari sifat-sifat: Nyawiji, bertekad golong-gilig baik berhubungan dengan Allah SWT maupun peraturan dengan sesama. Sifat Greget (tegas bersemangat), Sengguh (percaya diri penuh jati /harga diri) dan sifat Ora Mingkuh, tidak melepas tanggung jawab dan lari dari kewajiban. Maka figur satriya Ngayogyakarta ideal yakni seseorang yang dilengkapi pengageman Takwa. Bentuk pakaian Takwa adalah; Lengan panjang, ujung baju runcing, leher dengan kancing 3 pasang (berjumlah 6), dua kancing di dada kanan kiri, tiga buah kancing tertutup.

Lalu muncul surjan "ontrokusuma" yang bermotif bunga (kusuma) jenis dan motif kain yang digunakan untuk membuat surjan tersebut bukalah kain polos ataupun lurik buatan dalam negeri saja. Namun untuk surjan ontrokusuma terbuat dari kain sutra bermotif hiasan berbagai macam bunga. Surjan Ontrokusuma ini hanya kusus sebagai pakaian para bangsawan mataram. Ketika dalam lingkungan karaton baju ini hanya boleh dipakai oleh Sri Sultan saja ataupun oleh Pangeran Putra Dalem itupun atas perintah dari Sri Sultan sendiri.

Sumber: K.R.T. Jatiningrat, 2016, Rasukan Takwa lan Pranakan ing Karaton Ngayogyakarta Hadiningrat, Yogyakarta: Tepas Dwarapura Karaton Ngayogyakarta Hadiningrat.

\section{Filosofi}

Surjan menurut KRT Jatiningrat Tepas Dwarapura Keraton Yogyakarta berasal dari istilah siro + jan yang berarti pelita atau yang memberi terang. Surjan juga disebut pakaian "takwa". Oleh karena itu di dalam pakaian itu terkandung makna-makna filosofi yang cukup dalam, di antaranya bagian leher baju surjan memiliki kancing 3 pasang (6 biji kancing) yang kesemuanya itu menggambarkan rukun iman. Rukun iman tersebut adalah iman kepada Allah, iman kepada malaikat, iman kepada kitab-kitab, iman kepada utusan Allah, iman kepada hari kiamat, iman kepada takdir. Selain itu surjan juga memiliki dua buah kancing di bagian dada sebelah kiri dan kanan. Hal itu adalah simbol dua kalimat syahadat yang berbunyi, Ashaduallaillahaillalah dan Wa Ashaduanna Muhammada Rasulullah. Ada pula tiga buah kancing di dalam (bagian dada dekat perut) yang letaknya tertutup (tidak kelihatan) dari luar yang menggambarkan tiga macam nafsu manusia yang harus diredam/dikendalikan/ditutup. Nafsu-nafsu tersebut adalah nafsu bahimah (hewani), nafsu lauwamah (nafsu makan dan minum), dan nafsu syaitoniah (nafsu setan). Terdapat 5 kancing pada bagian lengan panjang kiri dan kanan. Angka 5 
lazim berkaitan dengan rukun Islam (syahadat, shalat, puasa, zakat, dan haji) dan juga lima priyagung dalam Islam (Nabi Muhammad, Kanjeng Sayidina Ngali, Gusti Sri Ayu Patimah, Gusti Bagus Kasan, dan Gusti Bagus Kusen).

Jenis pakaian atau baju ini bukan sekadar untuk fashion dan menutupi anggota tubuh supaya tidak kedinginan dan kepanasan serta untuk kepantasan saja, namun di dalamnya memang terkandung makna filosofi yang dalam. Pakaian takwa ini di dalam lingkungan Keraton Yogyakarta hanya diperkenankan dipakai oleh raja (sultan) dan para pangeran putra raja saja.

\section{Analisis Surjan Sebagai Simbol Budaya}

Post-modernisme dan Pendekatan Seni adalah dua aspek utama yang perlu dipertimbangkan dalam menilik kajian filosofis pakaian takwa/surjan ini. Baju menurut peneliti sendiri adalah merupakan karya seni yang sengaja diciptakan untuk kegunaan khusus. Aspek utama dalam teori ini membahas aspek objektif dan aspek subjektif. Aspek objektif berkaitan dengan pertimbangan berbagai faktor yang membatasi proses pengembangan seni, seperti teknologi, teknik, material, konvensi dan kode bahasa. Baju takwa sendiri dibuat dengan memiliki kode bahasa simbolik tersendiri. Aspek subjektif berkaitan dengan kemampuan artistik dan daya kreativitas seniman, yang dibentuk oleh kebudayaan, mitos, kepercayaan, ideologi atau ketaksadaran seniman itu sendiri. Pengageman takwa ini dibuat dengan melihat sejarahnya dibentuk dari kebudayaan dan kepercayaan Islam, dengan mengacu pada ideologi pembuatnya yaitu ideologi kemasyarakatan, kesederhanaan, kebersahajaan, dan memiliki jiwa ksatria.

Jika ditilik dari pendekatan post-modern terhadap seni, lebih memusatkan perhatian pada aspek formal dan fungsional. Pendekatan post-modern, sebaliknya lebih menekankan pada aspek permainan tanda dan kode-kode, memandang objek sebagai mozaik tanda-tanda. Pandangan objek dan objek seni sebagai mozaik tanda baik dalam konteks politik, ekonomi, dan sosiokultural telah dikembangkan oleh para pemikir sosial, bahasa, maupun seni, seperti Barthes, Eco dan Baudrillard.

Untuk mengkaji objek seni sebagai tanda, sama artinya menganggapnya sebagai komponen dari bahasa. Bahasa sendiri merupakan komponen dari sosial kebudayaan. Objek seni dalam hal ini, adalah komponen dari kebudayaan benda (material culture). Untuk mempelajari objek seni sebagai tanda sama artinya dengan mempelajari kebudayaan, dimana orang tersebut berada. Objek seni, dalam hal ini, dapat dikaji sebagai unit kebudayaan. Dengan demikian, ia berfungsi sebagai tanda, yang mempunyai referensinya pada fenomena kultural. Dengan memandang objek seni, kita dapat melihat bahwa ia merupakan milik lingkungan tertentu, kelompok tertentu, kelompok masyarakat tertentu, dan cara berpikir tertentu. Dapat dikatakan bahwa objek seni (baju takwa) menyatakan pertaliannya dengan sesuatu melalui bentuknya. Untuk mempelajari objek seni sebagai tanda adalah untuk menemukan kode-kode yang mengaturnya yang ada pada satu komunitas, kebudayaan, atau ruang tertentu.

Pandangan Barthes kode itu sendiri beraneka ragam bentuk, asal, dan latar belakang sosial budayanya. Menurut Eco, kode itu sendiri dapat menjadikan referensi berbagai unit kebudayaan, yang menurutnya bisa apa saja, ulai dari orang, tempat, perasaan, fantasi bahkan halusinasi. Unit baju takwa sendiri merupakan bentuk dari suatu sosial budaya 
Jawa yang Islami. Tercipta dari seseorang yang memiliki perasaan mulia terhadap makna kehidupan dari suatu lokasi yaitu jawa (Pialang, 2003: 216-217).

\section{Surjan sebagai Kode iconic Budaya Jawa}

\section{Simbol}

Dalam komunikasi antar budaya dikenal pula adanya pesan nonverbal. Komunikasi nonverbal meliputi tindakan-tindakan nonverbal yang tidak menggunakan kata-kata, salah satunya disebutkan dalam bukunya Liliweri (2009) adalah perbedaan budaya yang meliputi karakteristik personal (Janet Dexter, 1995 dalam Liliweri, 2009: 175).

Istilah nonverbal sendiri dikaitkan dengan kehadiran pesan dalam bentuk simbol (pengertian konotatif). Dalam komunikasi nonverbal yang terpenting adalah mencari makna (meaning). Simbol menurut Wednesday memiliki cara untuk berkaitan dengan rujukannya, salah satunya yaitu ikonik - sama atau mirip dengan objek atau konsep yang diterangkan oleh tanda (Liliweri, 2009: 177-179).

Berpakaian adalah sebuah bahasa, sebuah sistem nonverbal dari komunikasi karena melalui simbol itu ditemukan pribadi pemakai dan penikmatnya. Sebelum seseorang mulai bicara mengungkapkan jati dirinya, orang lain sudah bisa melihat status sosial, atau jenis kelamin orang tersebut dari pakaiannya (Liliweri, 2009: 211).

Dalam pendekatan kebudayaan khusus baju surjan dapat diartikan sebagai alat komunikasi nonverbal yang menjadi simbol ikonik yang menunjukkan batas-batas budaya dengan nilai budaya lainnya di Indonesia. Surjan sebagai pakaian adat Jawa dapat dipelajari sebagai bentuk hasil kebudayaan, nilai, norma, kepercayaan, sistem sosial dan budaya, sistem ekonomi, mata pencaharian dan adat istiadat di Jawa (Jogja pada khususnya).

\section{Identitas}

Menurut Romo Tirun identitas yang melekat pada saat seseorang mengenakan baju surjan adalah bahwa dia berarti orang Jawa (Jogja), beriman (bertakwa), menjunjung tinggi budi luhur masyarakat Jawa yang bermasyarakat berjiwa gotong-royong. Karena memang baju surjan terutama Lurik adalah ageman masyarakat pada zaman dahulu yang sudah melekat dengan identitas Jawa (Jogja) yang menjunjung budi luhur. Dan sebagai tanda keistimewaan karena hanya ada di Jogja.

\section{Budaya}

Menurut Romo Tirun budaya tidak terikat oleh batas Administrasi maupun wilayah tertentu, sehingga semua dapat menggunakan baju surjan tidak hanya orang-orang di karaton maupun di masyarakat Yogyakarta aja. Bahkan tidak terikat oleh agama, semua agama boleh memakai baju takwa ketika mengerti makna atau falsafah baju tersebut. Secara simbolik harus mengerti artinya dan dimaknai sebagai ajaran hidup. Simbol tersebut akhirnya menggambarkan bahwa Karaton Ngayogyakarta Hadiningrat adalah karaton yang Islami dasarnya. Hal tersebut menunjukkan bahwa budaya Islam di Indonesia sangat kuat, terutama di daerah Jawa. 


\section{Tradisi}

Tradisi berisi ritual-ritual yang dilakukan oleh masyarakat Jawa (Jogja) dengan menggunakan surjan salah satunya pada upacara Gerebeg. Gerebeg merupakan upacara selamatan kerajaan (wilujengan nagari) yang berupa upacara kurban (pada Grebeg Besar), atau sedekah (yang diwujudkan dengan gunungan) agar raja, kerajaan (keraton) dan rakyatnya diberi perlindungan, keselamatan, ketentraman.

Upacara Gerebeg diselenggarakan tiga kali dalam satu tahun, berupa Gerebeg Maulud, Gerebeg Besar, dan Gerebeg Puasa atau Gerebeg Syawal. Semua busana keprabon/kebesaran itu pada masa pemerintahan Sultan Hamengku Buwana IX sangat disederhanakan. Baik sultan maupun para pangeran hanya mengenakan busana Kejawen terdiri kain batik Parang Rusak Barong untuk Sultan, dan kain Barong yang lebih kecil ukurannya untuk para pangeran atau kain bermotif lainnya menurut selera para pangeran. Baju surjan, tutup kepala berupa udheng, tanpa asesoris.

Namun baju Surjan lurik biasa dapat dipakai masyarakat umum sehari-hari, karena memang baju surjan lurik dulunya adalah pakaian masyarakat Jogja. Saat ini pemerintahan Jogja sedang menghidupkan kembali pakaian surjan lurik untuk digunakan sebagai identitas kota yaitu setiap Hari Jadi Karaton Ngayogyakarta Hadiningrat setiap kamis pahing 35 hari sekali bagi laki-laki. Menurut KRT Jatiningrat baju surjan lurik lebih bagus (KRT Jatiningrat, 2016). Beliau juga mengatakan hal ini baik untuk meningkatkan usaha tenun di Jogja.

\section{Kajian Data Visual}

\section{Konsep Kreatif}

\section{a. Tagline}

Berfungsi sebagai keyword dalam bentuk pesan verbal yang disampaikan untuk memberikan inspirasi dan nilai positif terhadap target audiens. Keyword yang akan digunakan dalam perancangan ini adalah adalah "Menjadi Abdi Budaya, Bangga dalam Identitas Jawa". Terinspirasi dari K.M.T. Sukarno Abdi Dalem Karaton Ngayogyokarto Hadiningrat.

\section{b. Maskot/Ikon}

Dalam perancangan ini akan dibuat 6 ikon yang akan menampilkan pakaian takwanya masing-masing sesuai jenisnya yang nantinya akan digunakan untuk menjelaskan makna dan bentuk jenis pakaian takwa atau surjan yang dikenakan pada ikon tersebut. Hal ini dibuat agar target audiens tertarik dalam mengetahui pakaian takwa atau surjan lebih banyak lagi. Ilustrasi 6 ikon tersebut akan digambarkan berbentuk vektor dengan model flat desain. Ikon akan dibuat dengan unik dan simpel agar mudah diingat atau memorable.

\section{c. Strategi Kreatif}

Strategi kreatif dibuat untuk mencapai hasil yang maksimal dalam membuat desain informasi. Desain yang dibuat untuk menyampaikan informasi tertentu harus dapat 
menarik perhatian target audiens agar pesan yang ingin disampaikan tercapai. Untuk merancang desain informatif yang efektif maka digunakan strategi sebagai berikut:

\section{1) Merancang Isi Pesan (what to say)}

Isi pesan akan terkait dengan informasi mengenai filosofi, sejarah, mitos, jenis, dan makna baju takwa atau surjan. Pesan berupa informasi detail akan dimasukkan ke dalam media Blogspot.co.id. sehingga nantinya dalam layout utama pada ikon yang akan di share hanya akan dimasukkan informasi link. Hal tersebut merupakan strategi agar audiens tidak bosan terlebih dahulu dengan banyak informasi yang diberikan.

Pesan yang akan selalu keluar beserta 6 ikon surjan adalah keyword yang sudah dipilih dan dijelaskan sebelumnya. Yaitu "Menjadi Abdi Budaya, Bangga dalam Identitas Jawa". Lalu pesan pendukungnya akan dipilih sesuai hasil angket informasi mana yang paling rendah diketahui akan dimasukkan menjadi informasi pendukung di layout utama.

\section{2) Bentuk Pesan (How to say)}

Model layout yang akan menjadi sumber inspirasi dalam perancangan ini adalah layout:

Model Poster Paula Scher, dimana ia berkarya dengan karakter pragmatisnya antara era modernisme dan pascamodernisme yang mulai memanas. (Armstrong, 2010: 89). Model ini dipilih karena dinamis, memiliki blank area agar audiens tidak jenuh.

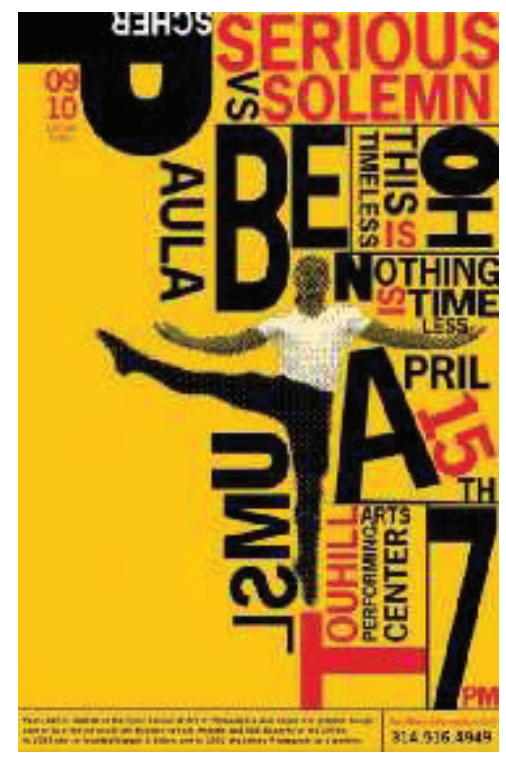

Gambar 01. Model Poster Paula Scher,

Sumber: www.pinterest.com

Model layout ini nantinya akan dimodifikasi dengan gaya ilustrasi flat design yang kekinian.

\section{a. Ilustrasi}

Illustrasi dalam perancangan ini akan dibuat berupa gambar vektor. Ilustrasi akan menampilkan orang yang mengenakan ragam pakaian takwa atau surjan. Dasar ilustrasi akan berdasarkan studi visual orang-orang dalam memakai pakaian takwa atau surjan. 
Ikon dalam perancangan ini terdapat 6 ikon yang nantinya akan merepresentasikan jenis surjan yang berbeda-beda. Dasar gaya visual yang akan digunakan dalam perancangan ini akan mengambil inspirasi dari Sunan Kalijaga dalam menggunakan pakaian takwa. Selanjutnya 6 desain ikon surjan yang berbeda mengambil inspirasi dari studi visual masyarakat yang memakai surjan. Berikut gambar yang diambil dari sumber internet visual Sunan Kalijaga menggunakan pakaian takwa.

\section{- Studi Visual Utama}

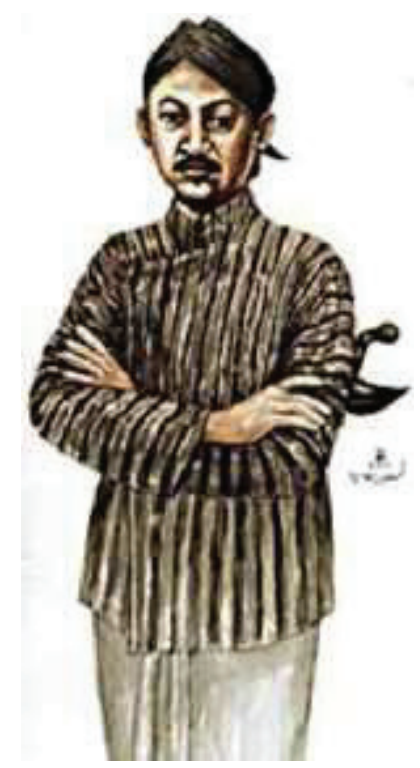

Gambar 02. Surjan Sunan Kalijaga Sumber: http://akucintanusantaraku.blogspot.co.id

- Studi Visual cara Masyarakat menggunakan Baju takwa atau Surjan

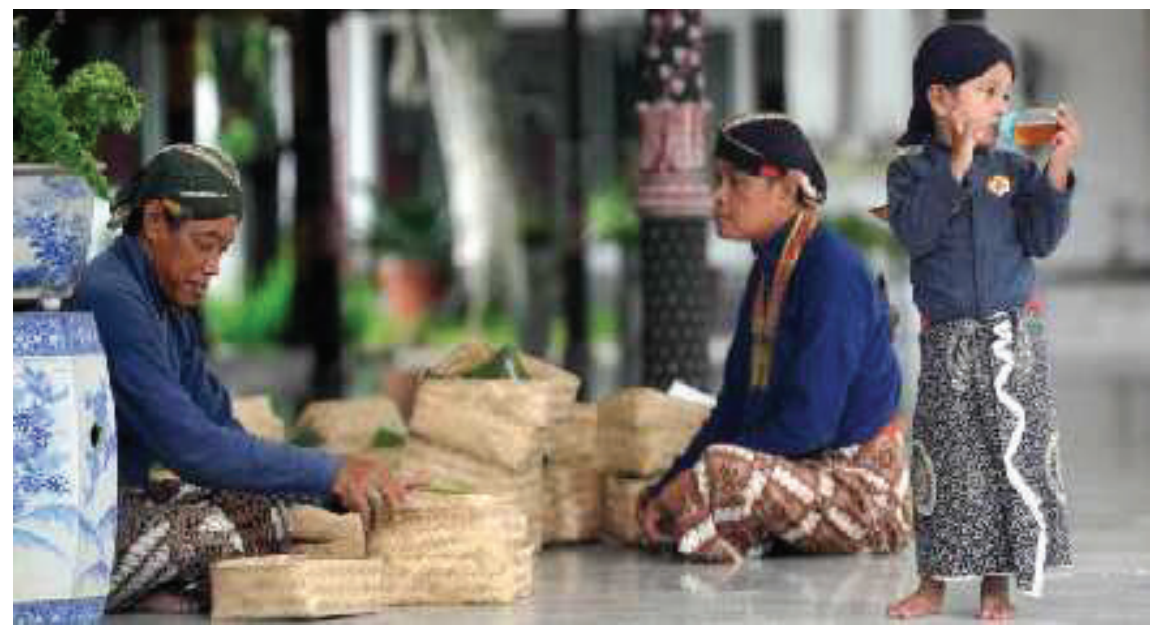

Gambar 03. Abdi Dalem Keraton menggunakan pakaian Peranakan, Sumber: http://www.piyunganonline.org 


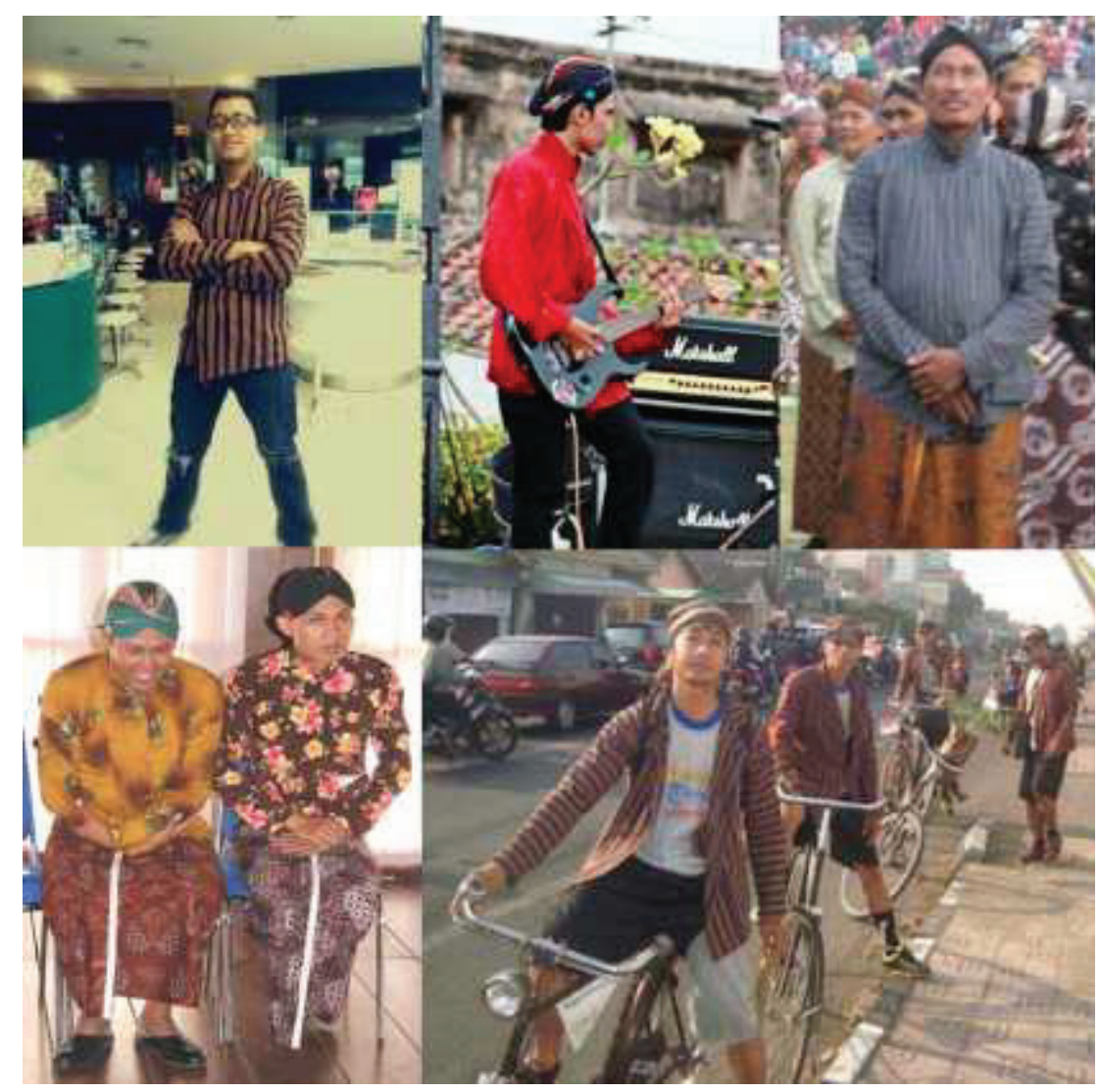

Gambar 04, 05, 06, 07, 08 Penampilan masyarakat umum menggunakan Surjan, Sumber: http://tembi.net

\section{b. Warna}

Pemilihan warna

Desain komunikasi ini nantinya akan memilih menggunakan warna-warna RGB. Model warna RGB adalah model warna berdasarkan konsep penambahan kuat cahaya primer yaitu Red, Green dan Blue. Dengan kombinasi warna tersebut perancangan ini akan dibuat. Alasannya warna-warna tersebut cenderung kontras dan dapat memberikan kesan dinamis (Supriyono, 2010: 70).

\section{d. Tipografi (font dan susunan huruf)}

Dalam perancangan ini huruf yang akan digunakan adalah tipe huruf San serif seperti Arial, Tunga, Impact. Jenis-jenis font tersebut memiliki bagian tubuh yang tebalnya sama. Huruf San Serif cukup efektif dipakai dalam penulisan judul atau teks yang pendek. Huruf san serif sering digunakan untuk buku dan majalah karena memiliki citra yang dinamis (Supriyono, 2010: 27). Berikut adalah tipe-tipe Huruf San Serif. 


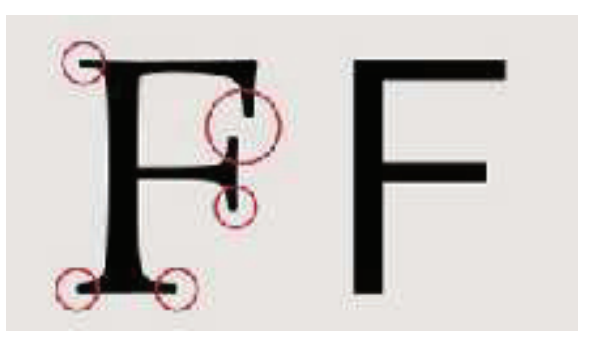

Gambar 09. Perbedaan Font Serif dan San Serif Sebelah Kiri adalah Font Serif memiliki kait dan yang Kanan San serif tidak memiliki kait, Sumber: https://www.fonts.com

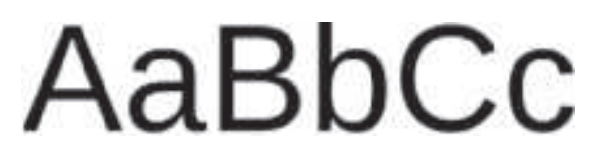

Gambar 10. San Serif, Sumber: https://en.wikipedia.org/wiki/Sansserifhttps://www.fonts.com

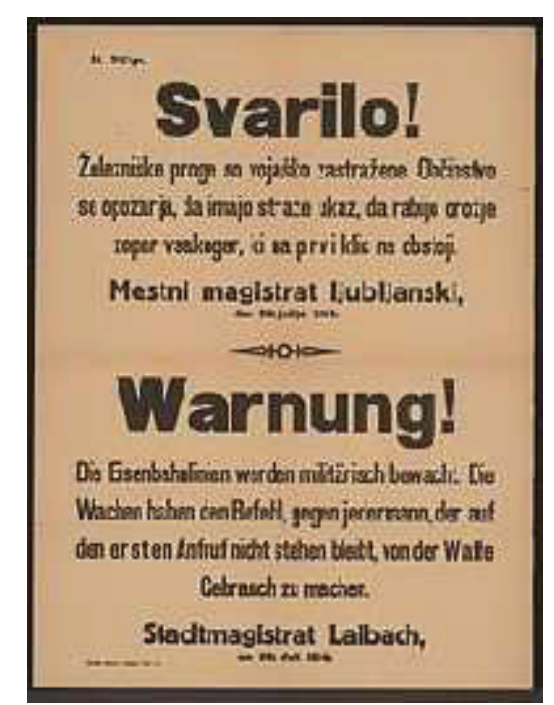

Gambar 11. di samping merupakan aplikasi Font San Serif pada Poster 1914, Sumber: https://en.wikipedia.org/wiki/Sansserif

\section{Program Penulisan Teks}

a. Media Utama

- Media Sosial : Facebook dan Instagram

Visual : Ilustrasi Ragam Surjan

Headline : "Memahami makna Surjan dalam Identitas Jawa"

Teks : : Key word dan informasi link website

- Website : Blogspot.co.id

Visual : Elemen-elemen visual yang mendukung tentang penjelasan baju takwa atau Surjan baik foto maupun gambar vektor.

Headline : "Identitas Surjan Yogyakarta"

Teks : seluruh informasi mengenai mitos, sejarah, budaya, jenis, makna, dan filosofi pakaian takwa

b. Media Pendukung Brosur yang dapat dijadikan Souvenir Paper Craft

Visual

: Ilustrasi Ragam Surjan

Teks

: informasi link website http://www.tentangsurjan.co.id

Dan aturan cara merangkai boneka paper craft surjan 


\section{Strategi Media}

\section{Konsep Media}

a. Tujuan Media

Memberikan informasi terkait mitos, sejarah, budaya, jenis, makna, dan filosofi pakaian takwa atau Surjan. Diharapkan dapat mengembangkan sektor-sektor terkait dengan pakaian tersebut dan dapat diangkat menjadi trend fashion selain batik dan dipatenkan di UNESCO sebelum diakui oleh negara lain lagi spereti batik.

\section{b. Strategi Media}

\section{1) Media Utama (Prime Media)}

Media Sosial dipilih karena banyak orang yang menggunakan dan cukup mudah dijangkau oleh desainer dengan biaya $0 \%$. Serta cukup efektif menjangkau semua kalangan, target audiens dapat meluas. Sedangkan website (blog) dipilih karena lebih dapat menampung banyak informasi dan dapat diperbaharui informasinya setiap saat. Strategi media dalam perancangan ini sangat mengacu pada human centered dimana audiens dibebaskan untuk boleh memilih ingin mengetahui jenis surjan seadanya dalam sosial media atau menjadi penasaran dengan detail informasi mengenai pakaian takwa tersebut. Ketika visual desain sudah di share di sosial media maka khalayak dapat memutuskan, yang langsung penasaran maka akan langsung menuju website yang dibuat, namun yang hanya sekedar ingin membaca maka akan terwakili dengan visualisasi pesan yang di share di media sosial. Kedua reaksi audiens tersebut sama-sama efektif dalam tujuan desainer menyampaikan pesan.

\section{2) Media Pendukung (Supporting Media)}

Brosur yang dapat dijadikan Souvenir Paper Craf

Visual : Ilustrasi Ragam Surjan

Teks : informasi link website http://www.tentangsurjan.co.id dan aturan cara merangkai boneka paper craft surjan

Media ini menjadi pendukung sebagai remainder dan komunikasi interaktif dari desainer kepada target audiens. Dipilih media paper craft karena biaya produksinya cukup terjangkau. Papercraft ini dibuat dengan harapan target audiens dapat meletakkan ikon surjannya dilokasi-lokasi sesuai kesukaan target. Konsep human centered dalam perancangan ini sangat membebaskan target audiens untuk bebas memilih tipe ikon surjan yang dia inginkan dan paling disukai. Brosur ini akan disebar di lokasi-lokasi wisata (target utamanya Keraton Yogyakarta).

\section{Visualisasi}

\section{Studi Visual}

Ikon dalam perancangan ini terdapat 6 ikon yang nantinya akan merepresentasikan jenis surjan yang berbeda-beda. Dasar gaya visual yang akan digunakan dalam perancangan ini akan mengambil inspirasi dari Sunan Kalijaga dalam menggunakan pakaian takwa. Selanjutnya 6 desain ikon surjan yang berbeda mengambil inspirasi dari studi visual masyarakat yang memakai surjan. Berikut gambar yang diambil dari sumber internet visual Sunan Kalijaga menggunakan pakaian takwa. 


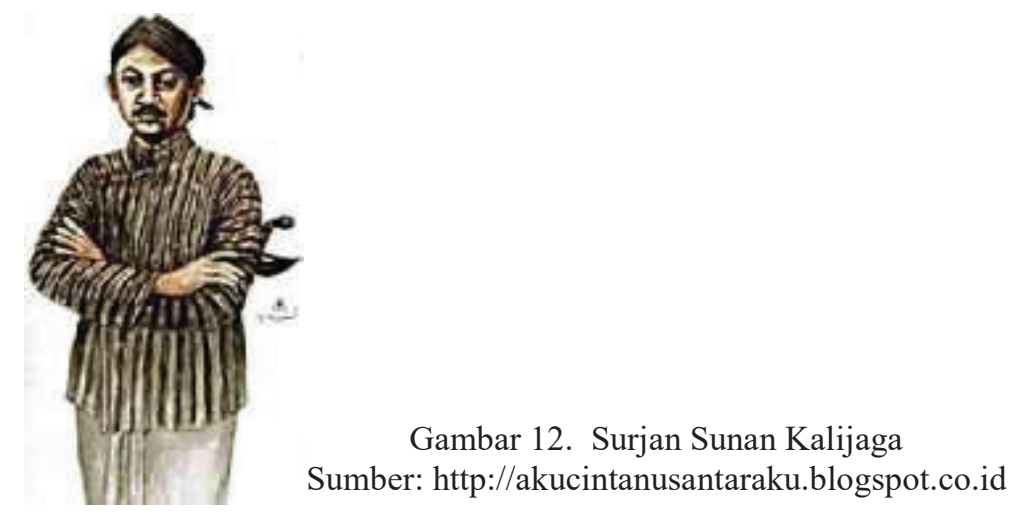

\section{Sketsa Kasar}

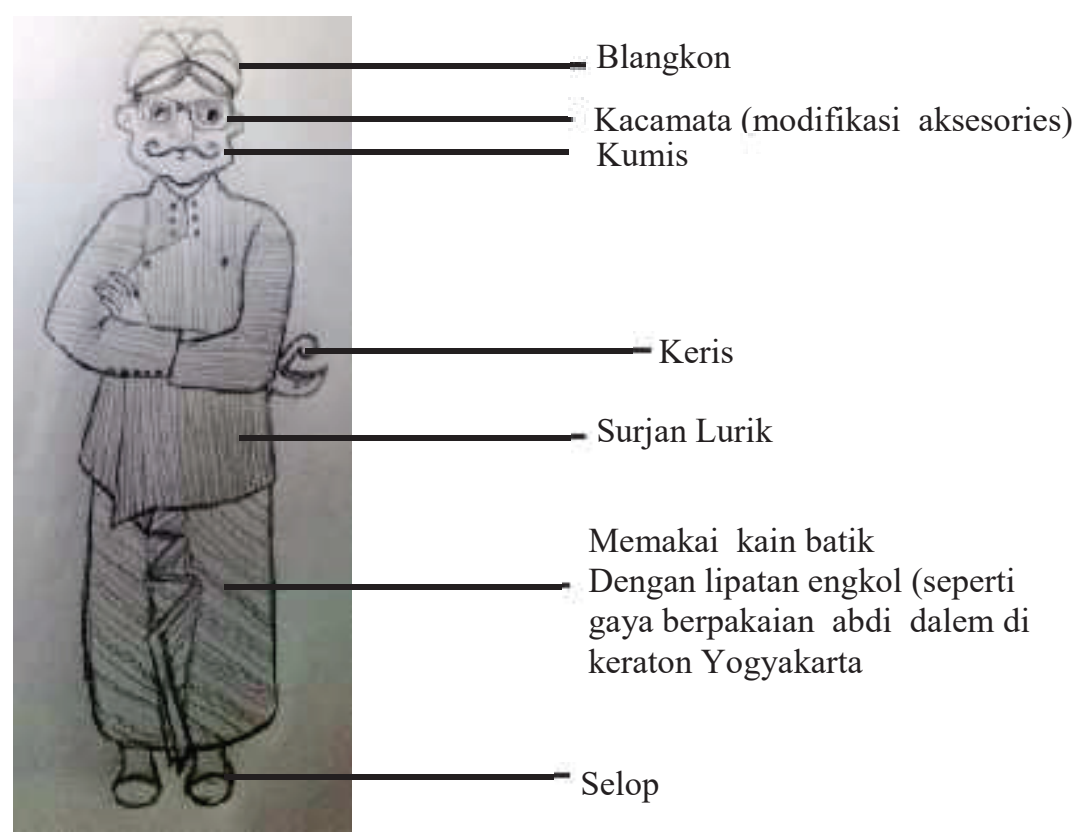

Gambar 13. Sketsa Kasar Ikon Surjan, Sumber: Pribadi 2016

\section{Desain awal}

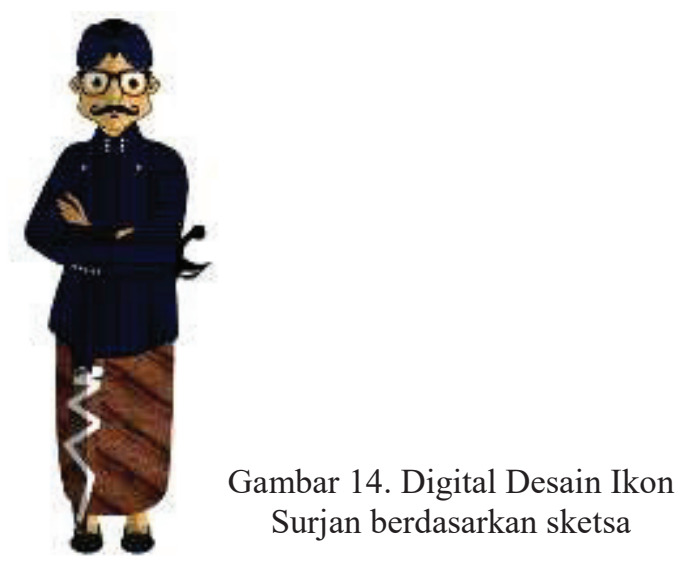




\section{Evaluasi Desain}

Setelah melakukan diskusi dengan dosen dan mencari komentar-komentar dari teman. Evaluasi yang didapatkan adalah bahwa posisi "sedakep" atau tangan dilipat memiliki makna psikologis yang kurang baik, yaitu bermakna acuh, sehingga tidak cocok dengan sifat orang jawa apalagi dengan filosofi pakaian takwa. Evaluasi ikon diganti dengan posisi tangan "ngapurancang" namun dengan konsep gambar yang sama. Berikut hasil dari evaluasi desain yang sudah didigitalkan.

Selain itu evaluasi yang dilakukan adalah kain batik, kain batik sebelumnya adalah jenis kain batik parang tuding, kain batik jenis tersebut jika dipasangkan kepada ikon yang mengacu pada pakaian takwa abdi dalem keraton tidak cocok, karena batik parang tuding jika di keraton hanya boleh digunakan oleh Sri Sultan (Raja).

Kain batik akhirnya diganti menjadi kain batik jenis grompol, yang memiliki arti berkumpul. Kain ini lebih cocok dengan filosofi para abdi dalem yang bekerja bersama-sama tidak individualis.

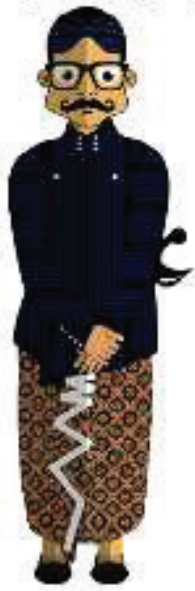

Gambar 15. Digital Desain Ikon Surjan berdasarkan sketsa yang telah dievaluasi

Selanjutnya 6 Desain Ikon yang berbeda mengacu pada gaya yang sama dengan desain tersebut hanya saja pakaiannya yang dirubah dan dimodifikasi berbeda-beda jenisnya.

\section{Final Desain Ikon 6 Jenis Pakaian Takwa}

Final desain ini akan digunakan untuk diaplikasikan ke berbagai media yang akan dipakai dalam penyampaian pesan. Final desain ini juga akan digunakan untuk membuat visualisasi paper craft sebagai souvenir (media pendukung).

\section{Ikon 1 dan 2 (Abdi Dalem Keraton Yogyakarta)}

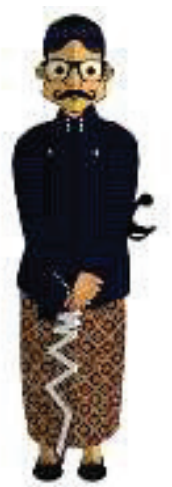

Gambar 16. Digital Final Desain Ikon Pakaian

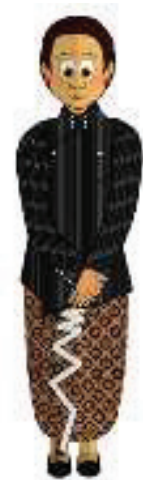

Gambar 17. Digital Final Desain Ikon Pakaian Takwa 


\section{Ikon 3 dan 4}
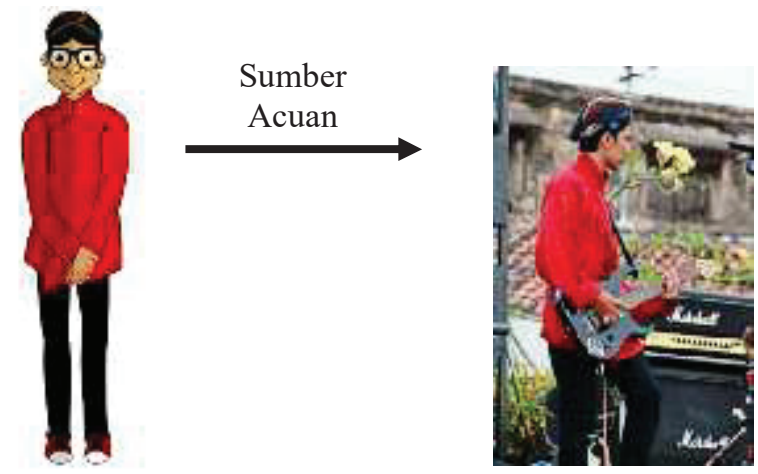

Gambar 18. Digital Final Desain Ikon Surjan Jagad

Foto ini dijadikan

Acuan Visualisasi Surjan

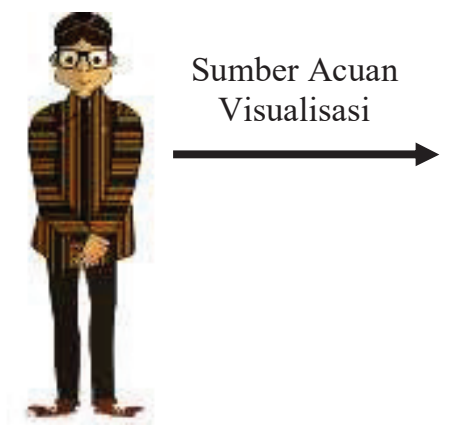

Gambar 19. Digital Final

Desain Ikon Surjan Lurik

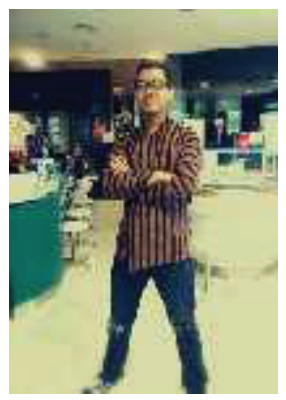

Foto ini dijadikan

Acuan Visualisasi Surjan Lurik

\section{Ikon 5 Surjan Ontrokusumo}

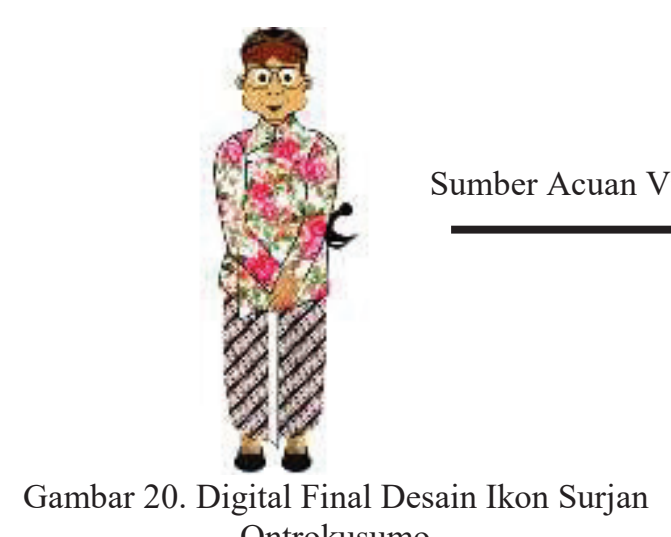
Ontrokusumo

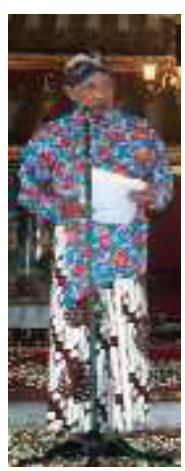

Foto 7. Sri Sultan HB X,

Sumber: http://www.siagaindonesia.com

Khusus untuk Surjan Ontrokusuma, karena jika di Keraton hanya boleh dipakai oleh Sri Sultan maka visualisasi tidak banyak dimiripkan, agar tidak ada pihak yang tersinggung oleh ilustrasi yang dibuat. Ilustrasi ini tetap mengacu pada gaya ilustrasi model awal yang dievaluasi menjadi "ngapurancang". 


\section{Ikon 6 Surjan Kesatriyan}
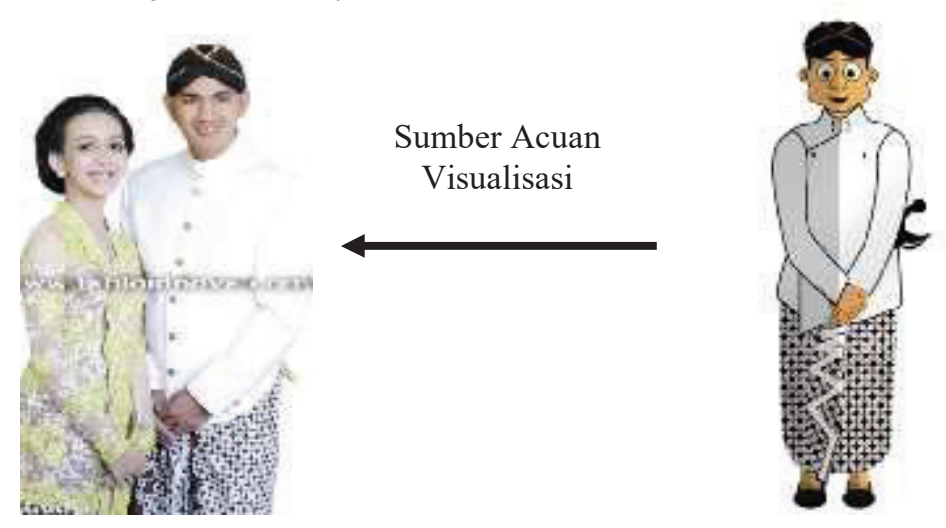

Foto 8. Mantu Sri Sultan HB X, Sumber: http://assets.tabloidnova.com

Gambar 21. Digital Final Desain Ikon Surjan Kasatriyan

\section{f. Desain Infografis}

Berikut adalah desain inforgrafis yang akan di share di media yang akan digunakan dalam perancangan ini.

1. Infografis Utama

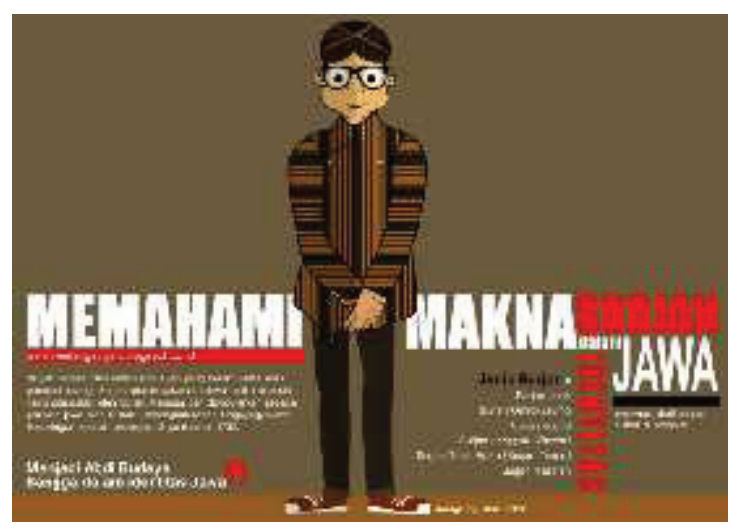

Gambar 22. Digital Final

Desain Info grafis Utama

2. Infografis Untuk Pakaian Takwa Peranakan

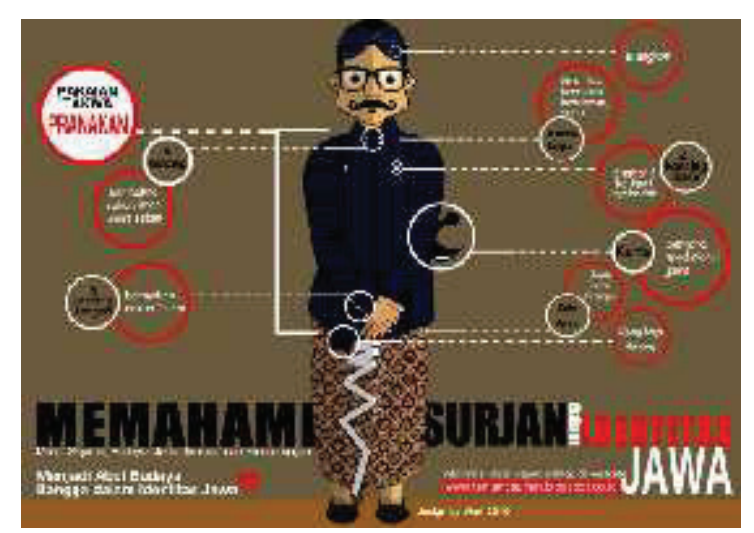

Gambar 23. Digital Final Desain Info grafis Pakaian Pranakan 
3. Infografis Untuk Pakaian Takwa Janggan

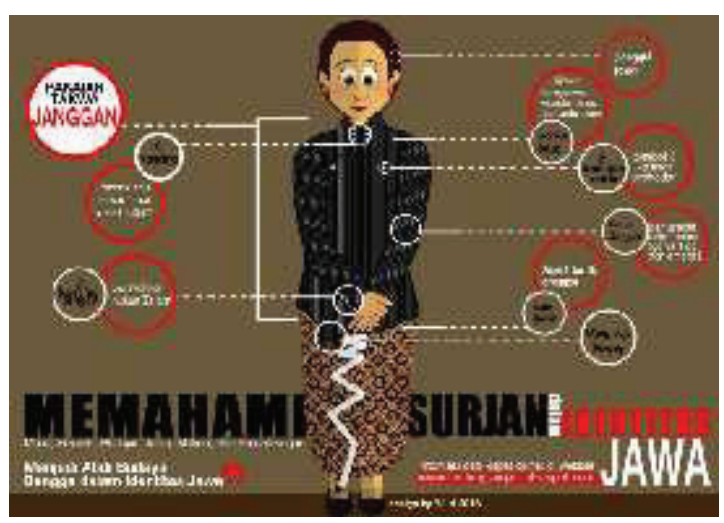

4. Infografis Untuk Surjan Lurik

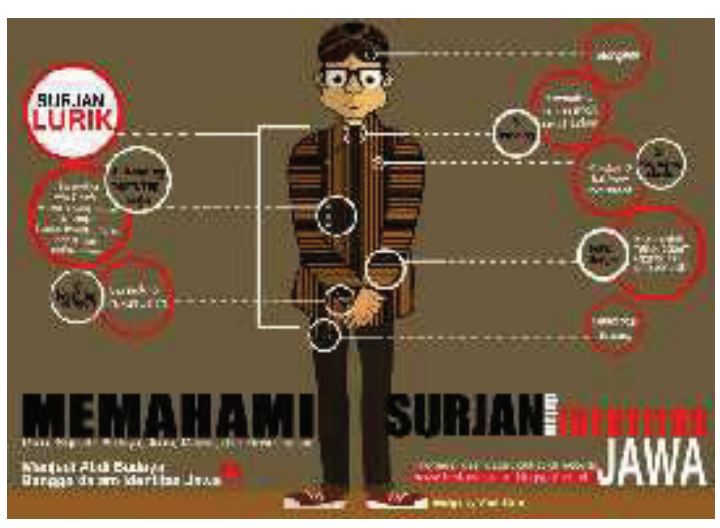

5. Infografis untuk surjan Jagad

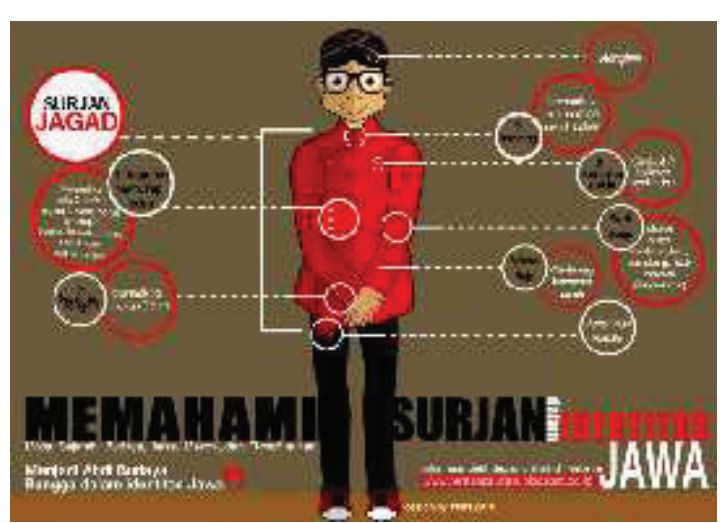

Gambar 24. Digital Final Desain Info grafis Pakaian Janggan

Gambar 25. Digital Final Desain Info grafis Pakaian Surjan Lurik

Gambar 26. Digital Final Desain Info grafis Surjan Jagad 
6. Infografis untuk Surjan Ontrokusumo

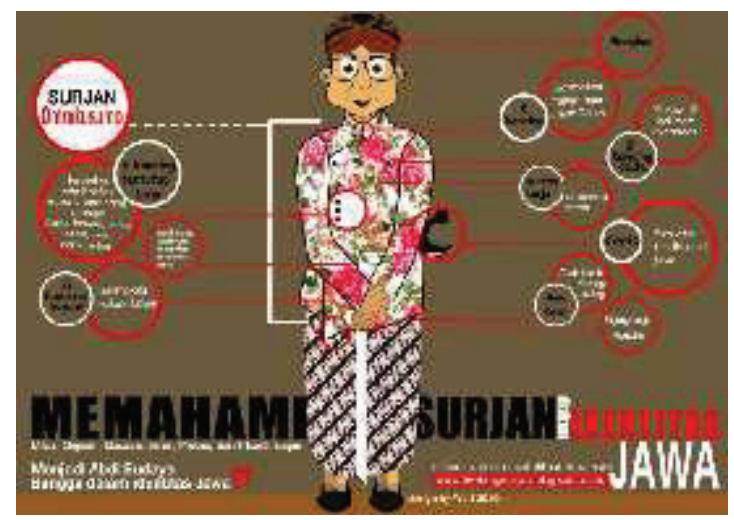

Gambar 27. Digital Final Desain Info grafis Surjan Ontrokusumo

7. Infografis untuk Surjan Kesatriyan

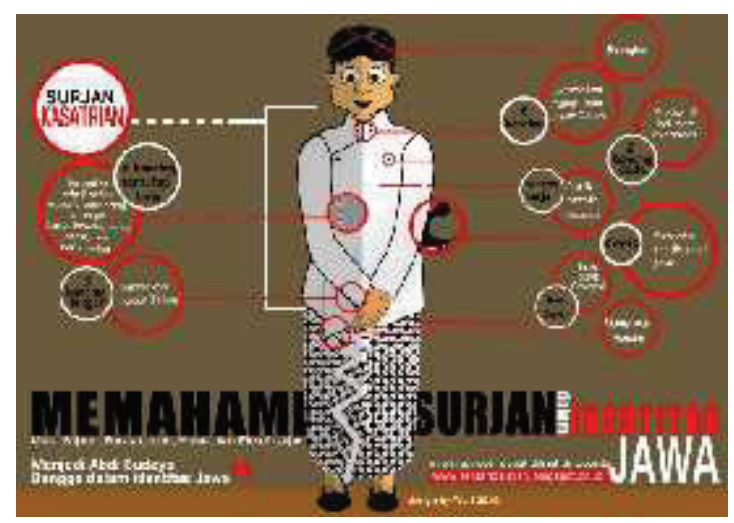

Gambar 28. Digital Final Desain Info grafis Surjan Kasatriyan

\section{Media Pendukung}

Berikut adalah desain paper craft sebagai media pendukung dalam penyampaian desain informasi tentang pakaian takwa. Disajikan desain kubus paper craft 6 ikon ilustrasi orang menggunakan jenis-jenis pakaian Takwa atau Surjan. Desain ini dibuat dengan tujuan dapat menjadi souvenir dan dapat menarik perhatian target audiens untuk mengetahui informasi tentang ageman Takwa atau Surjan lebih detail lagi dengan mencari informasinya melalui Link yang disisipkan dalam paper craft tersebut. Paper craft didesain agar user dapat membuat bonekanya sendiri dengan mudah. Di dalamnya disisipkan cara membuatnya sehingga user dapat mengikuti alur membuat boneka Surjannya sendiri. 
1) Model Lay-out Paper Craft yang akan Digunakan

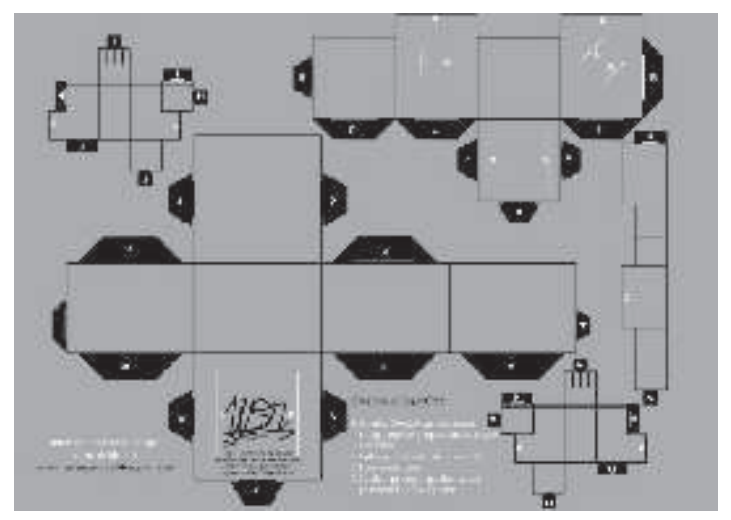

Gambar 29. Model Lay-out Paper

Craft Ikon Pakaian Takwa

\section{2) Paper Craft Pakaian Pranakan}

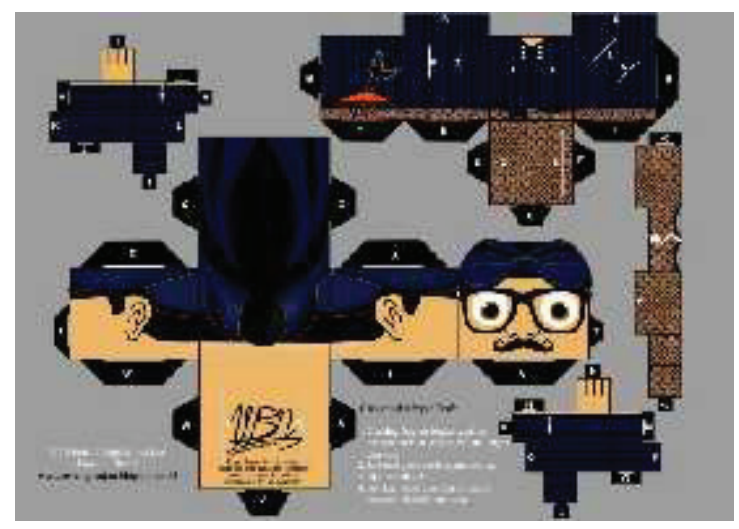

Gambar 30. Paper Craft Ikon

Pakaian Takwa Pranakan

\section{3) Paper Craft Pakaian Janggan}

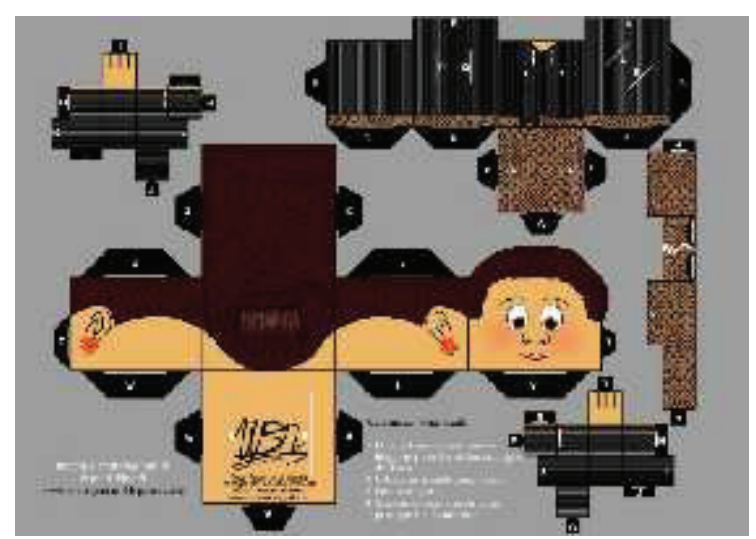

Gambar 31. Paper Craft Ikon Pakaian Takwa Janggan 


\section{4) Paper Craft Surjan Lurik}

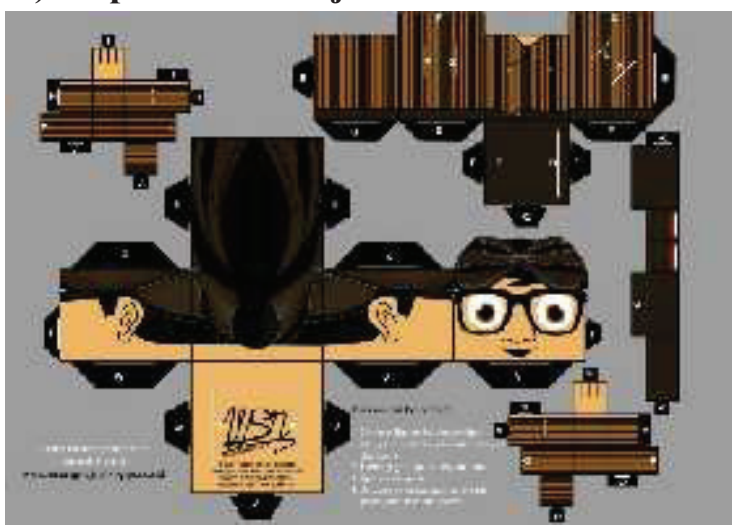

\section{5) Paper Craft Surjan Ontrokusumo}

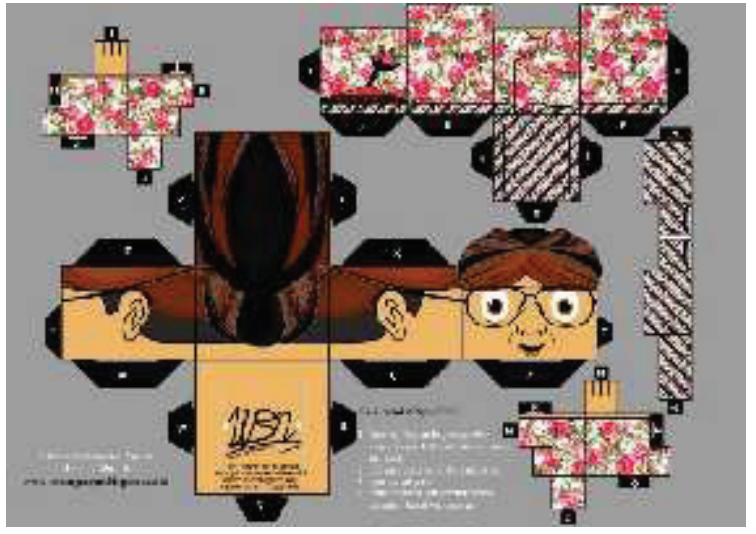

\section{6) Paper Craft Surjan Kasatriyan}

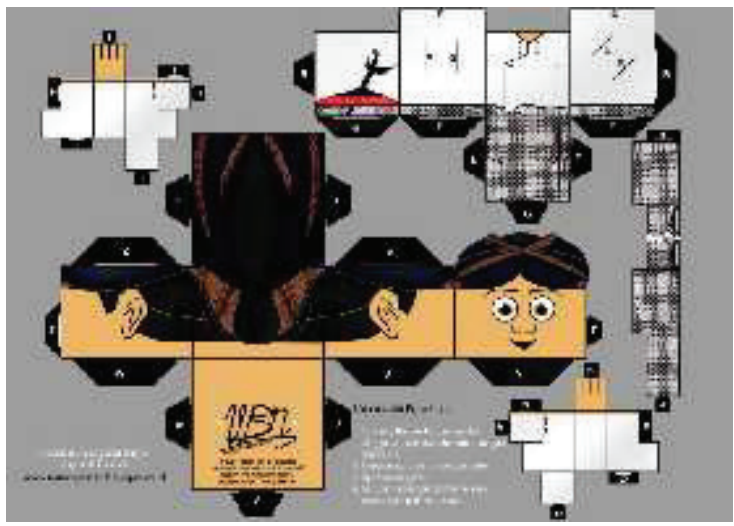

Gambar 32. Paper Craft Ikon Pakaian Surjan Lurik

Gambar 33. Paper Craft Ikon Pakaian Surjan Ontrokusumo

Gambar 34. Paper Craft Ikon

Pakaian Surjan Kasatriyan 
7) Paper Craft Surjan Jagad

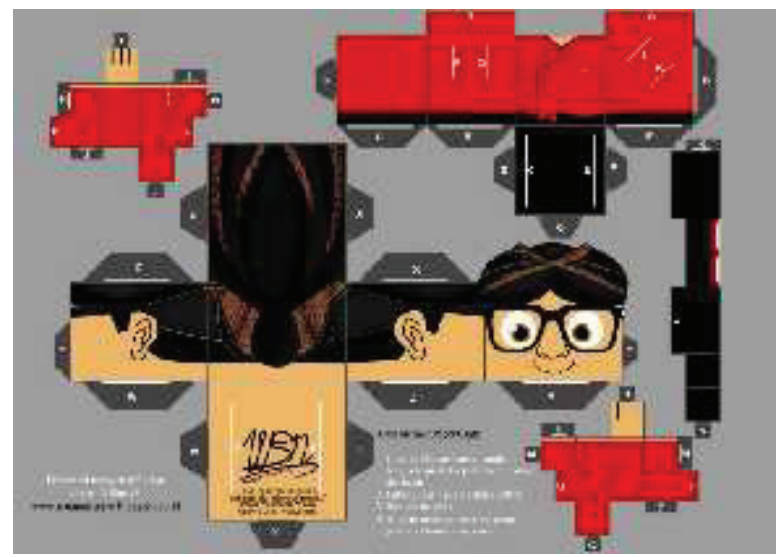

Gambar 35. Paper Craft Ikon Pakaian Surjan Jagad

\section{Kesimpulan}

Dengan metode Design Thinking Tim Brown desainer dapat dengan mudah memetakan 3 ruang agar inovasi dapat berjalan atau terjadi, yaitu: (1) inspiration, mencari permasalahan atau kesempatan yang mendorong terjadinya pemecahan permasalahan yaitu bahwa diketahui tidak banyak orang yang mengetahui tentang sejarah, nilai falsafah, ataupun makna dari bentuk baju Surjan Jogja; (2) ideation (proses membiak-kan, mengembangkan dan menguji ide) dari permasalahan tersebut akhirnya didapatkan inspirasi dan pengembangan untuk membuat desain yang dapat menginformasikan nilai filosofi dari Surjan Jogja. Lalu (3) implementation, yaitu tahap perancangan skema visualisasi desain komunikasi visual yang akan membantu menjembatani informasi mengenai filosofi Surjan Jogja secara efektif dan tepat sasaran.

\section{Kepustakaan}

Armstrong, Helen. 2010. "Graphic Design Theory Readings from the Field”. Yogyakarta: Penerbit Andi.

Bungin, Burhan. 2006. "Metodologi Penelitian Kuantitatif”. Jakarta: Kencana Media Group.

Liliweri, Alo. 2009. "Makna Budaya dalam Komunikasi Antarbudaya”. Yogyakarta: PT. LKiS.

Pialang, Yasraf Amir. 2003. "Semiotika dan Hipersemiotika (kode, gaya \& matinya makna”. Bandung: Matahari.

Ritzer, George. 2003. "(The Postmodern Social Theory) Teori Sosial Postmodern", Diterjemahkan oleh Muhammad Taufik. Yogyakarta: Kreasi Wacana.

Safanayong, Yongky. 2006. "Desain (Desain Komunikasi Komunikasi Visual Visual Terpadu)". Jakarta: Arte Intermedia.

Sarwono, Jonathan. 2007. "Metode Riset untuk Desain Komunikasi Visual”. Yogyakarta: Andi Offset (Penerbit Andi).

Supriyono, Rakhmat. 2010. "Desain Komunikasi Visual Teori dan Aplikasi". Yogyakarta: Penerbit Andi. 